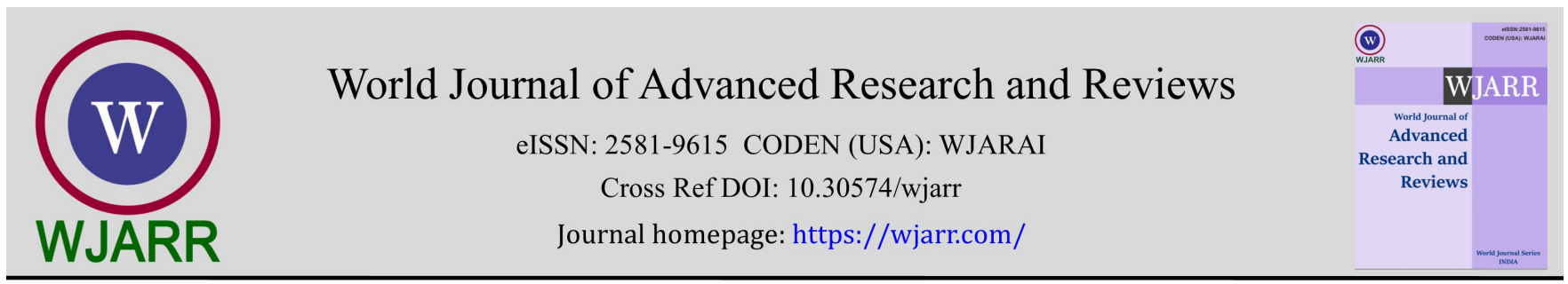

(REVIEW ARTICLE)

\title{
Influence of air pollution and meteorological parameters on COVID-19: An overview
}

\author{
Anbu Clemensis Johnson* \\ NUIST Reading Academy, 219 Ningliu Road, Nanjing, Jiangsu, 210044 P.R. China.
}

World Journal of Advanced Research and Reviews, 2021, 12(03), 580-586

Publication history: Received on 16 November 2021; revised on 26 December 2021; accepted on 28 December 2021

Article DOI: https://doi.org/10.30574/wjarr.2021.12.3.0715

\begin{abstract}
The spread of Covid-19 has been rampant across the globe, and studies have indicated a connection between the spike in infection and air pollution. The literature review has shown that the link between the SARS-CoV-2 virus causing the disease and air pollutants is still inconclusive. Current evidence from the studies point out two main contributing mechanisms for the spread of the virus: (1) the weakening of the human natural defence mechanism by the air pollutants facilitates virus entry and replication; (2) particulate matter facilitates the airborne transport of vectors. Meteorological parameters also play a significant role in the transmission of the virus. Ultraviolet radiation was negatively correlated with the number of COVID-19 cases, while wind speed was positively correlated. Temperature and humidity increases were associated with a decrease in the number of infections. Some studies have also shown no relationship between humidity and COVID-19 case numbers. Similarly, rainfall predominantly showed no significant correlation. More studies in this area are suggested to further understand the air pollutants effect on the virus, its interaction and the influence of meteorological parameters.
\end{abstract}

Keywords: Cilia; Nitrogen dioxide; Particulate matter; Temperature; Viral transport

\section{Introduction}

The COVID-19 outbreak began in Wuhan, China, sometime during November-December 2019 [1]. Later, in March 2020, the outbreak was classified as a pandemic by the World Health Organization [2]. Until recently, over 250 million people have been infected globally, leading to more than 5.1 million deaths [3]. The pathogen causing COVID-19 is SARS-CoV2 (severe acute respiratory syndrome coronavirus-2), which belongs to the coronavirus family [4]. Unlike the current pathogen, its predecessors MERS-CoV (Middle East respiratory syndrome coronavirus) which emerged in 2012, and the SARS-CoV (severe acute respiratory syndrome coronavirus) which appeared in 2003, were less contagious and the death toll was limited to 881 [5] and 774 [6]. The common symptoms exhibited by COVID-19 infected patients are, fever, cough, sore throat, runny nose, breathing difficulty, fatigue, body pain, headache, nausea, and diarrhoea [7]. With many of the symptoms resembling flu virus, there has been confusion and panic among patients across the world. Due to the virulence of the virus, many of the cities around the world went under lockdown for weeks to months, disrupting the economy and trade, while the benefit of the lockdown was the sudden decrease in atmospheric air pollutants.

It has been known that air pollutants have been connected to inducing various diseases and also found to aggravate existing medical conditions. Some ailments connected to exposure to air pollutants are, chronic obstructive pulmonary disease (COPD), asthma, and cardiovascular diseases [8]. In addition to road emissions, industrial accidents also contribute to existing air pollutant loads and pose a risk to people living in urban areas. Furthermore, meteorological factors also have been found to exacerbate the spread of COVID-19 infection. The objective of this study was to determine the association between air pollutants and COVID-19, and the influence of meteorological parameters towards the spread of coronavirus disease.

\footnotetext{
* Corresponding author Anbu Clemensis Johnson

NUIST Reading Academy, 219 Ningliu Road, Nanjing, Jiangsu, 210044 P.R. China.
}

Copyright (C) 2021 Author(s) retain the copyright of this article. This article is published under the terms of the Creative Commons Attribution Liscense 4.0. 


\section{Air pollutants}

Air pollutants in a region vary depending on the source. In addition to the particulate matter, nitrogen dioxide, sulphur dioxide, and carbon monoxide produced by the industries, they are also the cradle of numerous chemical compounds in the surrounding locality. The commonly measured criteria air pollutants are particulate matter $\left(\mathrm{PM}_{2.5}\right.$ and $\left.\mathrm{PM}_{10}\right)$, nitrogen dioxide $\left(\mathrm{NO}_{2}\right)$, sulphur dioxide $\left(\mathrm{SO}_{2}\right)$, carbon monoxide $(\mathrm{CO})$ and ozone $\left(\mathrm{O}_{3}\right)$, a secondary pollutant. The focus of this study is on these five pollutants, which have significant effects on human health and are associated with the spread of COVID-19.

\subsection{Effect of particulate matter on human health}

Primary sources of particulate matter are from combustion sources, especially from vehicles and industrial processes. Petrochemical reactions with gaseous pollutants (volatile organic compounds (VOCs), carbon monoxide (CO), nitrogen oxides $\left(\mathrm{NO}_{\mathrm{x}}\right)$, sulphur oxides $\left(\mathrm{SO}_{\mathrm{x}}\right)$, and ozone $\left(\mathrm{O}_{3}\right)$ ) also result in fine particles [9]. Important natural sources are wildfires and volcanoes. PM is further classified based on particle size. PM2.5-10 (diameter of particles between $2.5 \mu \mathrm{m}$ to $10 \mu \mathrm{m})$ particles predominantly deposit in the primary bronchi of the lungs. The fine particles (0.1 $\mu \mathrm{m}$ to $2.5 \mu \mathrm{m})$, can penetrate deeper into the lungs and reach the terminal bronchioles and alveoli. The ultra-fine particles $(<0.1 \mu \mathrm{m})$ could cross cell membranes and can interact with the cells [10-12]. The PMs effect on the human respiratory system is

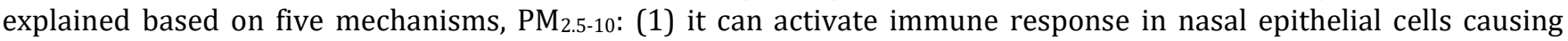
inflammation, (2) it can induce antigen-presenting cell-mediated inflammatory responses in the airway thereby suppressing the macrophages in the alveoli, $\mathrm{PM}_{2.5}$ : (3) induces oxidative stress in asthma, (4) leads to apoptosis and autophagy in asthma, ultra-fine particles: (5) can cause severe inflammation in asthma, resulting in alveolar macrophage chemotaxis and induce eosinophilic inflammatory responses [13-15].

\subsection{Effect of nitrogen dioxide on human health}

The main source of $\mathrm{NO}_{2}$ is combustion sources emitted from automobile engines and power plants. Symptoms associated with exposure to $\mathrm{NO}_{2}$ are, eye, throat, nose, and lung irritation [16]. It also causes burning sensations, spasms, and tissue swelling in the throat and respiratory track [17]. It increases the chances of asthma attacks and also aggravates medical conditions in patients with asthma $[18,19]$. Furthermore, it is linked to respiratory conditions such as, coughing, wheezing, dyspnea, bronchospasm, and pulmonary edema. It can cause an immune response when exposed to high concentrations. Chronic lung diseases and loss of sense of smell are also connected to exposure to $\mathrm{NO}_{2}$ [16].

\subsection{Effect of carbon monoxide on human health}

CO is produced when combustion of fossil fuels is incomplete. When a high concentration of CO builds up in the bloodstream, it results in CO poisoning. This is because of its high affinity towards hemoglobin compared to oxygen, which replaces oxygen in red blood cells. Typical early symptoms of poisoning are dizziness, headache, fatigue, and nausea. Progressed symptoms include confusion, blurry or double vision, vomiting, shortness of breath, chest pain, and loss of consciousness [20].

\subsection{Effect of sulphur dioxide on human health}

Sources of $\mathrm{SO}_{2}$ in the atmosphere include, burning fossil fuels containing sulphur in industrial activities, vehicles (especially diesel engines), and volcanic eruptions. $\mathrm{SO}_{2}$ can dissolve in water and when inhaled, it can form sulphurous and sulphuric acids [21]. These acids irritate the respiratory track and cause a burning sensation. This leads to bronchitis and asthma resulting in wheezing, phlegm, chest tightness and shortness of breath. Exposure to high levels reduces the lung's ability to function [22].

\subsection{Effect of ozone on human health}

Tropospheric ozone is formed from chemical reactions between volatile organic carbon and nitrogen oxides in the presence of ultraviolet light. Inhaled ozone has the ability to travel deeply into the lungs due to low water solubility [23]. It can cause coughing and throat irritation, breathing difficulty and pain, inflammation of the airways, and also has the potential to aggravate asthma, emphysema, and chronic obstructive pulmonary disease. Long-term exposure is also connected to the development of asthma [24,25]. 


\subsection{Effect of air pollutants of human respiratory system}

The bronchus is the pathway to the lungs, which consists of cilia (hairy projections). The cilia aid in moving pollutant particles and pathogens out of the airway. This is achieved through the goblet cells present in the cilia, which secrete mucus and play an important role in mucociliary clearance [26]. Impairment of cilia function and structure can affect mucociliary clearance and result in the contracting of various lung diseases [27]. Many studies have suggested that air pollutants affect the airway cilia and result in abnormalities of the mucociliary clearance leading the way to pathogenic infection and lung diseases [21,28-30]. Research conducted in 195 countries in 2015 indicated air pollutants to be a significant contributor to respiratory tract infections [31]. Higher concentrations of air pollutants also increased the occurrence of respiratory viral infections. Diseases associated with air pollution include, influenza, measles, respiratory syncytial virus, asthma, chronic obstructive pulmonary disease (COPD), bronchiolitis, acute respiratory distress syndrome (ARDS), and restrictive lung parenchyma diseases [32-35].

\subsection{Association between air pollution and COVID-19}

Initial association between increase in $\mathrm{PM}_{10}$ pollution $\left(>50 \mu \mathrm{g} \cdot \mathrm{m}^{-3}\right)$ and COVID-19 cases was observed in Italian provinces during February-March 2020 [36]. Study by Pansini and Fornacca [37] in eight countries have shown an increase in SARS-CoV-2 infections in regions with high $\mathrm{PM}_{2.5}$ and $\mathrm{NO}_{2}$ levels. Another study in China has shown that 10 $\mu \mathrm{g} \cdot \mathrm{m}^{-3}$ increase in particulate matter $\left(\mathrm{PM}_{2.5}\right.$ and $\left.\mathrm{PM}_{10}\right)$ had a rise in COVID-19 confirmed cases by $2.24 \%$ and $1.76 \%$ [38]. Similar observation was also noticed in more than 70 cities in China, and the effect was greater with $\mathrm{PM}_{2.5}$ [38]. Studies in Italy, Spain, Germany, France and the USA have shown increasing COVID-19 fatalities with higher $\mathrm{NO}_{2}$ levels $[39,40]$. A significant correlation between COVID-19 cases and deaths in California was observed with increases in $\mathrm{NO}_{2}$ concentrations [41]. Another study in China showed that with an increase in $10 \mu \mathrm{g} \cdot \mathrm{m}^{-3} \mathrm{of} \mathrm{NO}_{2}$ resulted in a $6.94 \%$ increase in the daily counts of COVID-19 cases [38]. An increase in CO concentration by $1 \mathrm{mg} \cdot \mathrm{m}^{-3}$ was associated with an increase in COVID-19 cases by $15.11 \%$ in China [38]. An opposite trend was observed with $\mathrm{SO}_{2}$ pollutant, as an increase in $\mathrm{SO}_{2}$ concentration by $10 \mu \mathrm{g} \cdot \mathrm{m}^{-3}$ was associated with the decrease in COVID-19 cases by $7.79 \%$. However, studies by Travaglio et al. [42] in England showed that when air quality was poor with $\mathrm{NO}$ and $\mathrm{SO}_{2}$, an increased rate of COVID-19 related deaths was observed. Urban $\mathrm{O}_{3}$ was also positively correlated with an increase in COVID-19 cases. An increase in $\mathrm{O}_{3}$ concentration by $10 \mu \mathrm{g} \cdot \mathrm{m}^{-3}$ resulted in an increase of $4.76 \%$ in daily counts of confirmed cases in China [38]. The study of the relationship between air pollutants and COVID-19 morbidity and mortality has shown that both COVID-19 and the air pollutants affect the same organs. The air pollutants can facilitate the entry of the virus into the body [43]. With weakening of the respiratory system, the severity of COVID-19 infection increases. The virus infects the ciliated cells present in the nasal epithelium, resulting in the loss of cilia [44]. The air pollutants are also connected to cardiovascular mortality and impairment of the neurological system $[45,46]$.

\section{Meteorological parameters}

Early studies have shown that climatic conditions can affect disease transmission [47]. The meteorological factors of a location vary from region to region and can influence the spread of coronavirus. Recently, various studies have analysed the influence of meteorological parameters on the spread of COVID-19 and have shown its relationship and significance [48-54]. The meteorological parameters considered in this study were ultraviolet radiation, temperature, humidity, rainfall, and wind speed.

\subsection{Airborne transport of COVID-19 and meteorological parameters}

The diameter of the SARS-CoV-2 virus is estimated to be approximately $0.1 \mu \mathrm{m}$ [55]. The virus becomes airborne through coughing and sneezing from infected patients through macro-droplets. The size of these aerosols (solid or liquid) can vary and particle size connected to COVID-19 transmission is less than $5 \mu \mathrm{m}[56,57]$. Studies have shown that SARS-CoV-2 can persist in air even after three hours or more after being emitted [58-60]. In the presence of air pollutants in the atmosphere, the virus can mix with the particles and can be suspended in the air $[10,61]$. Meteorological factors also play an important role in the virus transmission mechanism. Ultraviolet (UV) radiation and high temperature have an antibacterial effect on the COVID-19 virus [43]. Studies conducted in the USA (New York), Italy, China (17 different cities) and Indonesia have shown a decreasing trend in the number of COVID-19 cases with increasing temperature, while a study in Iran highlighted no significant relationship with temperature [49-53]. The presence of particulate matter in the air can reduce UV penetration ability and further aid the spread of infection [62]. Humidity and rainfall hydrate aerosol particles for virus persistence and sustenance and enhances transmission [63]. Studies conducted in Turkey and China (all provincial capitals) have shown a negative relationship with increase in humidity, which denotes a decrease in the number of confirmed cases, while a study conducted in the USA (New York) has shown no significant association between humidity and COVID-19 cases [49,51,54]. Similarly, studies in Iran and Indonesia (Jakarta) have shown no significant correlation with rainfall, while a study in Italy showed increased disease 
transmission with rainfall $[50,52,53]$. Wind speed has been shown to have a positive correlation with the spread of the infection in studies conducted in the USA, Iran and Turkey $[49,53,54,64]$. Dry air also facilitates viral transport and cold conditions can affect the function of the ciliated cells in the airway, aiding infection [65].

\section{Conclusion}

The literature review has shown a positive connection between air pollution episodes and the COVID-19 pandemic. The study revealed that different air pollutants can have a synergic negative effect on the human respiratory system. Air pollutants have the ability to weaken the body's natural defence mechanisms, which facilitates the entry of the virus. Air pollutants can also harbour and aid in its transport. On the contrary, sulphur dioxide has been found to decrease the spread of the infection. Meteorological conditions also tend to facilitate airborne transmission and thereby increase the infection rate. UV radiation has a negative correlation as higher temperatures can decrease virus transmission, while no significant relationship between temperature and COVID-19 has also been reported. Low temperatures on the other hand, can enhance the spread of infection. Humidity was either negatively correlated or with no significant correlation. Rainfall was predominantly shown to have no significant correlation with COVID-19 cases, whereas wind speed was positively correlated with the spread of the virus.

\section{Compliance with ethical standards}

\section{Acknowledgments}

This research did not receive any specific grants from funding agencies in the public, commercial, or not-for-profit sectors.

\section{Disclosure of conflict of interest}

The author declares no conflict of interest.

\section{References}

[1] Wikipedia. COVID-19 [Internet]. USA: CDC; 2021 [cited 2021 Nov 15]. Available from: https://en.wikipedia.org/wiki/Coronavirus_disease_2019\#cite_note-Symptoms_of_COVID19_CDC_Interim_Guidance-22.

[2] WHO. WHO Director-General's opening remarks at the media briefing on COVID-19 - 11 March 2020 [Internet]. USA: WHO; 2020 [cited 2021 Nov 15]. Available from: https://www.who.int/directorgeneral/speeches/detail/who-director-general-s-opening-remarks-at-the-media-briefing-on-covid-19---11march-2020.

[3] Worldometer. COVID-19 Coronavirus Pandemic [Internet]. USA: Worldometer; 2021 [cited 2021 Nov 15]. Available from: https://www.worldometers.info/coronavirus/\#countries.

[4] Lu R, Zhao X, Li J, Niu P, Yang B, Wu H, et al. Genomic characterisation and epidemiology of 2019 novel coronavirus: implications for virus origins and receptor binding. Lancet. 2020 Feb; 395(10224): 565-74.

[5] CIDRAP. Saudi MERS rise includes hospital outbreak cases [Internet]. USA: University of Minnesota; 2020 [cited 2021 Nov 15]. Available from: https://www.cidrap.umn.edu/news-perspective/2020/07/news-scan-jul-062020.

[6] CDC. SARS (10 Years After) [Internet]. USA: U.S. Department of Health \& Human Services; 2016a [cited 2021 Nov 15]. Available from: https://www.cdc.gov/dotw/sars/index.html.

[7] CDC. Interim Clinical Guidance for Management of Patients with Confirmed Coronavirus Disease (COVID-19) [Internet]. USA: U.S. Department of Health \& Human Services; 2021b [cited 2021 Nov 15]. Available from: https://www.cdc.gov/coronavirus/2019-ncov/hcp/clinical-guidance-management-patients.html.

[8] Manisalidis I, Stavropoulou E, Stavropoulos A, Bezirtzoglou E. Environmental and Health Impacts of Air Pollution: A Review. Front. Public Health. 2020 Feb; 8(14): 1-13.

[9] Lai A, Chang ML, Donnell RPO, Zhou C, Sumner JA, Hsiai TK. Association of COVID-19 transmission with high levels of ambient pollutants: Initiation and impact of the inflammatory response on cardiopulmonary disease. Science of the Total Environment. 2021 Jul; 779: 146464. 
[10] Kelly FJ, Fussell JC. Size, source and chemical composition as determinants of toxicity attributable to ambient particulate matter. Atmos Environ. 2012 Dec; 60: 504-526.

[11] Becker S, Soukup JM, Sioutas C, Cassee FR. Response of human alveolar macrophages to ultrafine, fine, and coarse urban air pollution particles. Exp Lung Res. 2003 Jan-Feb; 29: 29-44.

[12] Wilson WE, Suh HH. Fine particles and coarse particles: concentration relationships relevant to epidemiologic studies. J Air Waste Manag Assoc. 1997 Dec; 47: 1238-1249.

[13] Calderon MA, Devalia JL, Prior AJ, Sapsford RJ, Davies RJ. A comparison of cytokine release from epithelial cells cultured from nasal biopsy specimens of atopic patients with and without rhinitis and nonatopic subjects without rhinitis. J Allergy Clin Immunol. 1997 Jan; 99: 65-76.

[14] Ozturk AB, Bayraktar R, Gogebakan B, Mumbuc S, Bayram H. Comparison of inflammatory cytokine release from nasal epithelial cells of non-atopic non-rhinitic, allergic rhinitic and polyp subjects and effects of diesel exhaust particles in vitro. Allergol Immunopathol (Madr). 2017 Sep-Oct; 45: 473-481.

[15] Wu JZ, Ge DD, Zhou LF, Hou LY, Zhou Y, Li QY. Effects of particulate matter on allergic respiratory diseases. Chronic Diseases and Translational Medicine. 2018 Jun; 4: 95-102.

[16] Chen TM, Gokhale J, Shofer S, Kuschner WG. Outdoor air pollution: nitrogen dioxide, sulfur dioxide, and carbon monoxide health effects. Am J Med Sci. 2007 Apr; 333: 249-56.

[17] Envirojustice. Health effects of SO2, NOx and coal dust [Internet]. Australia: Environmental Justice Australia; 2021 [cited 2021 Nov 15]. Available from: https://www.envirojustice.org.au/our-work/community/airpollution/health-effects-of-so2-and-nox/.

[18] Irceline. What is the danger of N02? How can it make you sick? [Internet]. Belgium: Belgian Interregional Environment Agency; 2021 [cited 2021 Nov 15]. Available from: https://www.irceline.be/en/documentation/faq/what-is-the-danger-of-no2-how-can-it-make-you-sick.

[19] EPA. Basic Information about NO2. [Internet]. USA: U.S. Environmental Protection Agency; 2021 [cited 2021 Nov 15]. Available from: https://www.epa.gov/no2-pollution/basic-information-about-no2.

[20] Verywellhealth. Symptoms of Carbon Monoxide Poisoning [Internet]. USA: Dotdash Meredith, Inc.; 2021 [cited 2021 Nov 15]. Available from: https://www.verywellhealth.com/carbon-monoxide-poisoning-symptoms4161052.

[21] Cao Y, Chen M, Dong D, Xie S, Liu M. Environmental pollutants damage airway epithelial cell cilia: Implications for the prevention of obstructive lung diseases. Thoracic Cancer. 2020 Mar; 11: 505-510.

[22] American lung association. Sulfur Dioxide [Internet]. USA: American lung association; 2020 [cited 2021 Nov 15]. Available from: https://www.lung.org/clean-air/outdoors/what-makes-air-unhealthy/sulfur-dioxide.

[23] Hatch GE, Slade R, Harris LP, McDonnell WF, Devlin RB, Koren HS, et al. Ozone dose and effect in humans and rats. A comparison using oxygen-18 labeling and bronchoalveolar lavage. Am J Respir Crit Care Med. 1994 Sep; 150 : 676-83.

[24] Nuvolone D, Petri D, Voller F. The effects of ozone on human health. Environ Sci Pollut Res. 2018 Mar; 25: 807488.

[25] Koman PD, Mancuso P. Ozone exposure, cardiopulmonary health, and obesity: a substantive review. Chem Res Toxicol. 2017 Jul; 30: 1384-95.

[26] Medlineplus. Respiratory cilia. [Internet]. USA: National Library of Medicine; 2021 [cited 2021 Nov 15]. Available from: https://medlineplus.gov/ency/imagepages/19533.htm.

[27] Bennett WD. Effect of beta-adrenergic agonists on mucociliary clearance. J Allergy Clin Immunol. 2002 Dec; 110 : S291-7.

[28] Whitsett JA. Airway epithelial differentiation and mucociliary clearance. Ann Am Thorac Soc. 2018 Nov; 15: S1438.

[29] Houtmeyers E, Gosselink R, Gayan-Ramirez G, Decramer M. Regulation of mucociliary clearance in health and disease. Eur Respir J. 1999 May; 13: 1177-88.

[30] Pedersen M. Ciliary Activity and Pollution. Lung. 1990 Dec; 168: 368-376. 
[31] Troeger C, Forouzanfar M, Rao PC, et al. Estimates of the global, regional, and national morbidity, mortality, and aetiologies of lower respiratory tract infections in 195 countries: a systematic analysis for the Global Burden of Disease Study 2015. Lancet Infect Dis. 2017 Nov; 17: 1133-1161.

[32] Su W, Wu X, Geng X, et al. The short-term effects of air pollutants on influenza-like illness in Jinan, China. BMC Public Health. 2019 Oct; 19: 1319.

[33] Chen G, Zhang W, Li S, et al. Is short-term exposure to ambient fine particles associated with measles incidence in China? A multi-city study. Environ Res. 2017 Jul; 156: 306-311.

[34] Atkinson RW, Butland BK, Anderson HR, et al. Long-term concentrations of nitrogen dioxide and mortality: a meta-analysis of cohort studies. Epidemiology. 2018 Jul; 29: 460-472.

[35] Conti S, Harari S, Caminati A, et al. The association between air pollution and the incidence of idiopathic pulmonary fibrosis in Northern Italy. Eur Respir J. 2018 Jan; 51: 1700397.

[36] Frontera A, Cianfanelli L, Vlachos K, et al. Severe air pollution links to higher mortality in COVID-19 patients: the "double-hit" hypothesis. J Infect. 2020 Aug; 81: 255-259.

[37] Pansini R, Fornacca D. Higher virulence of COVID-19 in the air-polluted regions of eight severely affected countries. Atmosphere. 2021 Jun; 12: 795.

[38] Zhu Y, Xie J, Huang F, Cao L. Association between short-term exposure to air pollution and COVID-19 infection: Evidence from China. Science of the Total Environment. 2020 Jul; 727: 138704.

[39] Ogen Y. Assessing nitrogen dioxide $\left(\mathrm{NO}_{2}\right)$ levels as a contributing factor to coronavirus (COVID-19) fatality. Sci Total Environ. 2020 Jul; 726: 138605.

[40] Liang D, Shi L, Zhao J, et al. Urban Air Pollution May Enhance COVID-19 Case-Fatality and Mortality Rates in the United States. The Innovation. 2020 Nov; 1(3): 10004.

[41] Bashira MF, Ben Jiang MA, Bilal Komal B, Bashir MA, Farooq TH, Iqbal N, Bashir M. Correlation between environmental pollution indicators and COVID-19 pandemic: a brief study in Californian context. Environ. Res. 2020 Aug; 187: 109652.

[42] Travaglio M, Yu Y, Popovic R, Selley L, Leal NS, Martins LM. Links between air pollution and COVID-19 in England. Environmental Pollution. 2021 Jan; 268: 115859.

[43] Bourdrel T, Annesi-Maesano I, Alahmad B, Maesano CN, Bind MA. The impact of outdoor air pollution on COVID19: a review of evidence from in vitro, animal, and human studies. Eur Respir Rev. 2021 Dec; 30: 200242.

[44] Li W, Li M, Ou G. COVID-19, cilia, and smell. The FEBS Journal. 2020 Sep; 287(17): 3672-3676.

[45] Hoek G, Krishnan RM, Beelen R, et al. Long-term air pollution exposure and cardio- respiratory mortality: a review. Environ Health. 2013 May; 12: 43.

[46] Ajmani GS, Suh HH, Pinto JM. Effects of ambient air pollution exposure on olfaction: a review. Environ Health Perspect. 2016 Nov; 124: 1683-1693.

[47] Wu X, Lu Y, Zhou S, Chen L, Xu B. Impact of climate change on human infectious diseases: Empirical evidence and human adaptation. Environment International. 2016 Jan; 86: 14-23.

[48] Alkhowailed M, Shariq A, Alqossayir F, Alzahrani OA, Rasheed Z, Al Abdulmonem W. Impact of meteorological parameters on COVID-19 pandemic: A comprehensive study from Saudi Arabia. Informatics in Medicine Unlocked. 2020 Aug; 20: 100418.

[49] Bashir MF, Ma B, Bilal Komal B, Bashir MA, Tan D, Bashir M. Correlation between climate indicators and COVID19 pandemic in New York, USA. Sci. Total Environ. 2020 Aug; 728: 138835.

[50] Sobral MFF, Duarte GB, Sobral AIGP, Marinho MLM, Melo AS. Association between climate variables and global transmission of SARS-CoV-2. Sci.Tot. Environ. 2020 Aug; 729: 138997.

[51] Liu J, Zhou J, Yao J, Zhang X, Li L, Xu X, He X, Wang B, Fu S, Niu T, Yan J, Shi Y, Ren X, Niu J, Zhu W, Li S, Luo B, Zhang K. Impact of meteorological factors on the COVID-19 transmission: a multi- city study in China. Sci.Tot. Environ. 2020a Jul; 726: 138513.

[52] Tosepu R, Gunawan J, Effendy SD, Ahmad LOAI, Lestari H, Bahar H, Asfian P. Correlation between weather and covid-19 pandemic in Jakarta, Indonesia. Science Sci. Tot. Environ. 2020 Jul; 725: 138436. 
[53] Ahmadi M, Sharifi A, Dorosti S, Ghoushchi SJ, Ghanbari N. Investigation of effective climatology parameters on COVID-19 outbreak in Iran. Sci. Total Environ. 2020 Aug; 729: 138705.

[54] Sahin M. Impact of weather on COVID-19 pandemic in Turkey. Sci. Tot. Environ. 2020 Aug; 728: 138810.

[55] Bar-On YM, Flamholz A, Phillips R, Milo R. SARS-CoV-2 (COVID-19) by the numbers. Elife. 2020 Apr; 2(9): e57309.

[56] Liu Y, Ning Z, Chen Y, et al. Aerodynamic analysis of SARS-CoV-2 in two Wuhan hospitals. Nature. 2020b Apr; 582: 557-560.

[57] Morawska L, Cao J. Airborne transmission of SARS-CoV-2: the world should face the reality. Environ Int. 2020 Jun; 139: 105730.

[58] Van Doremalen N, Bushmaker T, Morris DH, et al. Aerosol and surface stability of SARS-CoV-2 as compared with SARS-CoV-1. N Engl J Med. 2020 Apr; 382: 1564-1567.

[59] UKRI. How long can coronavirus survive outside of the body? [Internet]. UK: Department of Health \& Social Care; 2020 [cited 2021 Nov 15]. Available from: https://coronavirusexplained.ukri.org/en/article/pub0008/.

[60] EPA. Indoor Air and Coronavirus (COVID-19). [Internet]. USA: United States Environmental Protection Agency; 2021 [cited 2021 Nov 15]. Available from: https://www.epa.gov/coronavirus/indoor-air-and-coronaviruscovid-19.

[61] Kalisa E, Archer S, Nagato E, et al. Chemical and biological components of urban aerosols in Africa: current status and knowledge gaps. Int J Environ Res Public Health. 2019 Mar; 16: 941.

[62] Welch D, Buonanno M, Grilj V, et al. Far-UVC light: a new tool to control the spread of airborne-mediated microbial diseases. Sci Rep. 2018 Feb; 8: 2752.

[63] Haddrell AE, Thomas RJ. Aerobiology: experimental considerations, observations, and future tools. Appl Environ Microbiol. 2017 Aug; 83: e00809-17.

[64] Srivastava A. COVID-19 and air pollution and meteorology-an intricate relationship: A review. Chemosphere. 2021 Jan; 263: 128297.

[65] Moriyama M, Hugentobler WJ, Iwasaki A. Seasonality of respiratory viral infections. Annu Rev Virol. 2020 Sep; 7: 83-101. 